CASE REPORT

\title{
Rehabilitation Program for Transverse Myelitis
}

\section{John Hartono, Tanti Ajoe Kesoema, Robby Tjandra Kartadinata}

Department of Physical Medicine and Rehabilitation, Dr. Kariadi General Hospital, Faculty of Medicine, University of Diponegoro, Semarang, Indonesia

\begin{abstract}
Introduction: Transverse myelitis is a neurological disease involving inflammation or lesions on the spinal cord with rapid and progressive onset of symptomsMotor training, sensory stimulation, and rehabilitation of autonomic functions are needed, to restore the function, reduce disability, and improve the quality of life.

Case Presentation: A 34 years old male had weakness and loss of sensoric of lower limbs, accompanied by low back pain (LBP), chronic cough, and micturition dysfunction for 1 month ago, categorized by ASIA impairment scale (AIS) D, level of injury at T6. The MRI of Thoracolumbal showed myelitis lession at 6 th -7 th of thoracal, effusion at facet joint of L2-L5, and lumbal spondylosis. The rehabilitation programs were active range of motion exercise with walking exercise (3 session/week, 30 minutes/ session), Transcutaneous Electrical Nerve Stimulation (2-10 pps, 2 session/week, 20 minutes/session), sensory stimulation ( 2 session/week, 20 minute/session), and bladder training for 3 weeks. After 16 days, there were lower limb's strength improvement by Manual Muscle Testing (MMT) were average four at level L2-S1, sensory improvement to T9-10, LBP was reduced, and normal micturition. After 3 weeks, lower limb strength improved to 55445/55445 at level L2-S1. Patient able to walk without assisted.
\end{abstract}

Conclusion: Muscle strengthening, sensory simulation and bladder training, combined with pharmacological treatment, improved motor, sensory and autonomic function in Transverse Myelitis patient

Keywords: Motoric training, sensory stimulation, bladder training, Transcutaneous electrical nerve stimulation, transverse myelitis 


\begin{abstract}
ABSTRAK
Pendahuluan: Transverse myelitis merupakan gangguan neurologis berupa peradangan atau lesi pada tulang belakang dengan gejala yang cepat dan progresif. Latihan motorik, stimulasi sensorik, dan rehabilitasi fungsi otonom diperlukan untuk memperbaiki fungsi, menurunkan disabilitas, dan meningkatkan kualitas hidup.
\end{abstract}

Presentasi Kasus: Seorang pria berusia 34 tahun dengan gejala kelemahan kedua ekstremitas inferior, disertai nyeri punggung bawah (NPB), batuk kronik, dan kesulitan berkemih 1 bulan lalu. MRI Thoracolumbal menunjukkan lesi mielitis pada diskus thorakalis 6-7, efusi sendi facet di L2-L5 dan spondylosis lumbalis. Pasien dikategorikan AIS D, dengan level cedera di T6. Terapi rehabilitasi untuk mielitis transversal, berupa gerak sendi aktif dan latihan jalan ( $3 \mathrm{sesi} / \mathrm{minggu}, 30 \mathrm{menit} / \mathrm{sesi})$, stimulasi elektrik pada saraf secara transkutan (2-10 pps, 2 sesi/minggu, 20 menit/sesi), stimulasi sensorik (2 sesi/ minggu, 20 menit/sesi), dan pelatihan kandung kemih selama 3 minggu.

Pada hari ke 16 terjadi peningkatan kekuatan ekstremitas inferior rerata tingkat empat dengan uji otot secara manual (MMT) pada tingkat L2-S1, perbaikan sensorik pada tingkat T9-10, perbaikan NPB, dan fungsi miksi normal. Setelah 3 minggu, kekuatan ekstremitas inferior menjadi 55445/55445. Pasien dapat berjalan tanpa alat bantu.

Kesimpulan: Program rehabilitasi medik yang terdiri dari penguatan otot, simulasi sensorik dan pelatihan kandung kemih, dikombinasikan dengan farmakologis, meningkatkan fungsi motorik, sensorik dan otonom pada pasien Transverse Myelitis.

Kata kunci: Latihan motoric, stimulasi sensorik, latihan kandung kemih, Stimulasi elektrik saraf transkutan, Transverse myelitis

\section{Correspondent Detail:}

\section{John Hartono}

Email: dr.john.hartono@gmail.com

Department of Physical Medicine and Rehabilitation, Dr. Kariadi General Hospital, University of Diponegoro,

Semarang, Indonesia

\section{INTRODUCTION}

Transverse myelitis is a neurological disease involving inflammation or lesions on the spinal cord with rapid and progressive onset of symptoms, including back pain, weakness, sensory and autonomic dysfunction. ${ }^{1-3}$ Most Transverse Myelitis cases related with the immune system disorders, but infection from viral, bacterial, fungal and even from parasite could also related to the Transverse Myelitis. Other etiology is vascular disorders such as arterial-venous malformation, dural arterial-venous fistula, intraspinal cavernous malformation or disc embolism. It is estimated that about 1,400 new cases of transverse myelitis are diagnosed each year in the United States. It is estimated that about 33,000 
Americans have some type of disability resulting from transverse myelitis. The annual incidence of transverse myelitis ranges from 1.34 to 4.60 cases per million, but increase to 24.6 cases per million if acquired demyelinating diseases like MS and neuromyelitis optica (NMO) are included. ${ }^{4}$

MRI examination could reveal the lesion on the spinal cord, but CSF analysis is recommended, with pleocytosis and elevated $\operatorname{IgG}$ index as sign of inflammation ${ }^{5,6}$. First line pharmacological treatment is high dose corticosteroid. In cases caused by autoimmune condition, Plasma exchange therapy (plasmapheresis) and Intravenous immunoglobulin (IVIG) were used. In this case, antibiotic was used as bacterial infection is suspected as the main caused of the myelitis. ${ }^{6}$

Transverse Myelitis rehabilitation has the same specific goals like any other case related to the spinal cord injury, which is to restore the lost function or return it to a level as close as possible to the one exhibited prior to the injury. Motoric, sensory and autonomic dysfunction symptoms are treated with combination of motoric training, such as range of movement with addition of strengthening exercises will help to reach better outcome, with patient optimal ambulation ability as the main rehabilitation goals. In severe motoric deficit cases, neuromuscular electrical stimulation modalities can be used to help with the movement and strengthening program. Sensory stimulation kits, such as brush, contoured plateau, therapeutic ball, etc. are used to stimulate the sensory deficit dermatome area. Serial bladder training is used to retrain bladder muscle for the voiding function as in this case we found urine retention condition (autonomic dysfunction). Functional Electrical Stimulation can also be used in retraining the bladder. Other rehabilitation modalities, such as TENS can be used for the back pain symptoms related with Transverse Myelitis. Patient prognosis of the transverse myelitis patient ranges variably, with $50 \%$ patient complete recovery, $40 \%$ patient shows mild deficits and $10 \%$ poorly improve from the disease. ${ }^{5,6}$

\section{CASE REPORT}

A 34 years old male patient, Mr. AR, was referred to the Dr. Kariadi General Hospital, from the local private hospital due to the progress of weakness of both lower extremities that caused the patient unable to walk, and urinary retention problem, since 20 days before the referral. Patient had been catheterized during his hospitalization at the local hospital. Patient also complained about his back pain (NPRS 5) and decreased of sensory function from his upper abdominal level down to both of his feet. American Spinal Injury Association (ASIA) impairment scale (AIS) has showed motor and sensory level injury both at level T6 with neurogenic bladder dysfunction (urine retention) and normal bowel function, and concluded as AIS D. Patient already had a cough for at least one month. There was no history of chronic diseases. Patient was a mason, and usually lifting heavy load, that has discontinue the job due to this illness.

Laboratory findings have shown a leukocytosis $(16.800 / \mathrm{uL})$, high urinary sediment of leucocyte $(820.5 / \mathrm{uL})$ with high bacterial concentration $(++/ 25520.4 / \mathrm{uL})$. The sputum examination during the hospitalization has found the colony of diplococcus, with no findings of tuberculous bactery. 
Thoracolumbalis MRI has shown a hyperintense lesion at the posterior side of spinal cord at $6^{\text {th }}$ $7^{\text {th }}$ thoracal intervertebral disc, which suggest a myelitis accompany by degenerative end plate superior $4^{\text {th }}$ and $5^{\text {th }}$ Lumbar (MODIC type 2), also facet joint effusion around $2^{\text {nd }}-5^{\text {th }}$ lumbar, which could also related to the patient's low back pain.

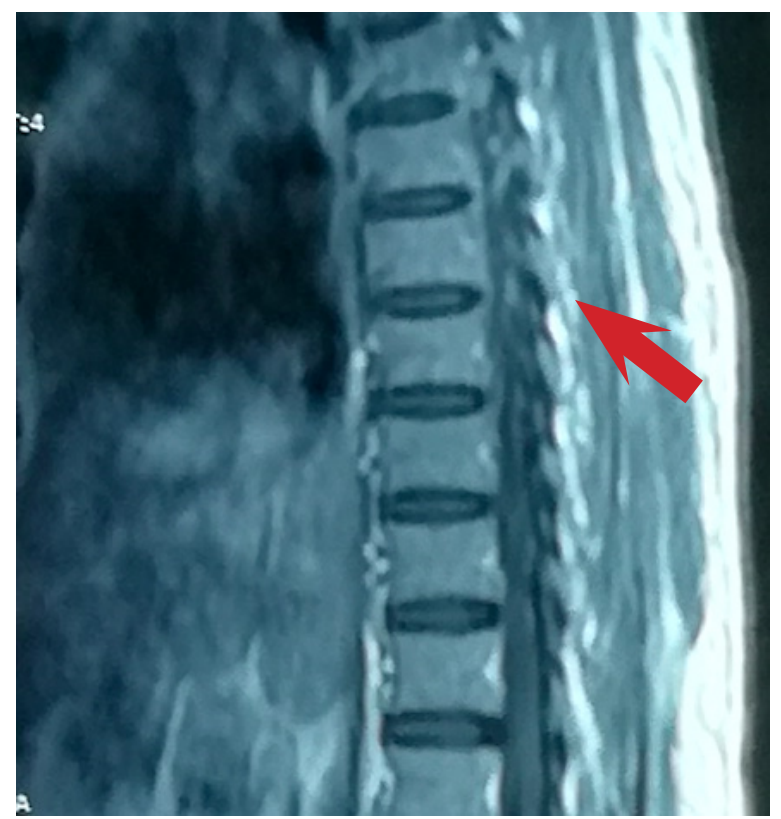

Figure 1. MRI Sagital View Thoracal VI-VII

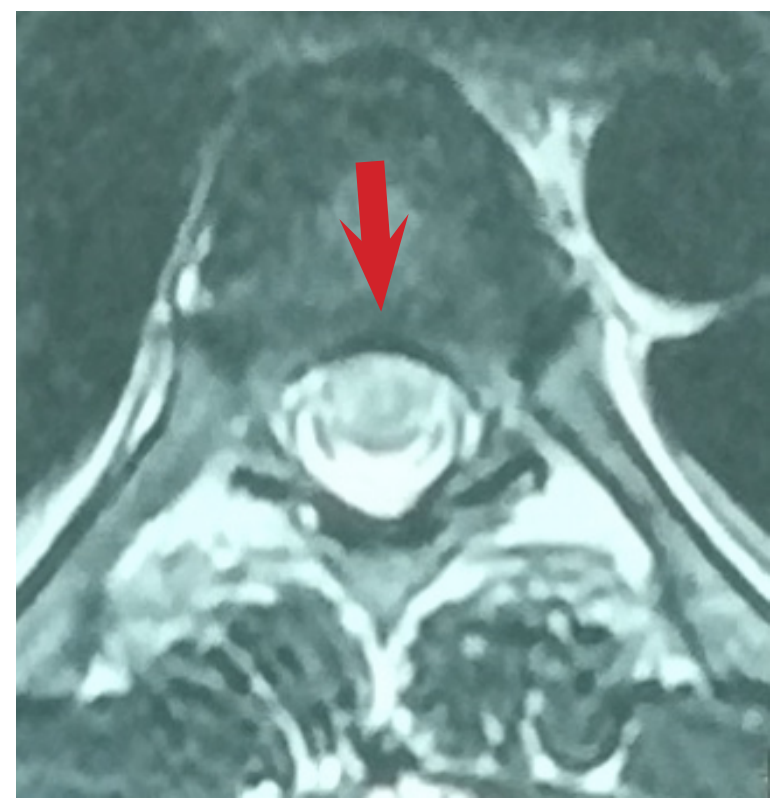

Figure 2. MRI Axial View segment Thoracal VI-VII
On the first rehabilitation assessment $\left(2^{\text {nd }}\right.$ day after admission), patient showed weakness on both lower extremities, able to stand up but with difficulty to walk (patient tend to feel back pain and more weakness at the left side limb). From patient's lower extremities muscles, MMT examination scored 44434/44334, with left side sensory deficits as high as T7 with pin prick test and T9 with fine touch. Due to the urinary retention, a urinary catheter already placed ( $8^{\text {th }}$ day) to help patient micturition (patient already had urinary catheterized since 20 days before admission). Patient still able to defecation, and still have morning erection. Other neurological examinations shown there was no abnormality.

From internal medicine division examination, patient found to have a chronic cough for 1 month, and then get further laboratory test for sputum test due to suspect of tuberculosis infection, even though the thorax $\mathrm{x}$-ray was normal. Sputum test shown Diplococcus colony with no BTA found. Patient was still on schedule to run the Mantoux test to check for suspected latent tuberculosis infection. No CSF Analysis had been done for this patient.

The International Classification of Functioning, Disability and Health (ICF) were used for the patient's functional diagnosis. The problem was at the spinal cord level, with primary defect area at thoracal vertebral disc (ICF s12001 thoracic spinal cord); body function problem as the patient had bilateral lower extremities weakness (b7303 - paraparese inferior), patient also had low back pain (ICF b28013- pain in back) and patient had bladder function problem (ICF b6200 - urination) also patient had skin sensory deficit (ICF b840 - sensation related to 
the skin); Patient had mobility activity problem of difficulty to walk properly due to muscle weakness and back pain (ICF d4500- walking short distance), patient had no personal factor problem as he had a good motivation to get better and willing to follow all the treatment program. Patient's participation function had a problem due to the patient unable to work (d8451-maintaining a job), patient's job required him to lift and move heavy weight on daily basis work load, this will caused a problem because beside patient had Transverse Myelitis with back pain, there were also sign of vertebral degenerative at the lumbar level. There was no environment problem for patient. ${ }^{7}$

Patient's rehabilitation program consist of active assistive range of motion (AAROM) exercises, i.e. Straight Leg Raise, Heel Slide, Ankle Pumping of the lower extremities with manually resistance by the Therapist, contrary to exercises movement (ie. Flexion force for Extension exercise moves) to strengthen lower limb muscles. These exercises scheduled for 3 sessions/week, 30 minutes/session; followed by walking exercise with 3 session/week for 15-20 minutes/session or as patient tolerated. The low back pain treated by low rate of transcutaneous electro nerve stimulation (TENS) ; 2-10 pps on the lumbar region, 2 times per week, as well as 2 sessions of sensory stimulation exercise per week; 20 minutes/session. All rehabilitation sessions handled by therapists, and under supervision of Physical Medicine and Rehabilitation Specialist.

Beside, patient and family educated to do AAROM exercises routinely (in bed or sitting position, up to 2- 3 times/day, 2 days/week) and tried to walk around his bed as tolerated, to optimize the function.
Bladder training program started on $3^{\text {rd }}$ day admission with constant micturition evaluation every 1-2 hours interval, gradually increased interval time, as patient tolerated, up to 3-4 hours interval of micturition. In 3 weeks of hospitalization, patient has 5 days/week physical exercise (AAROM plus resistance exercise and walking exercise); 9 sessions with therapist and 3 out of 6 personal schedule; 6 session of lumbar TENS and 6 session of sensory stimulation. Patient had 3 days of bladder training before the urinary catheter removed.

\section{RESULTS}

During 3 weeks of hospitalization, Physical Medicine \& Rehabilitation division run 3 times of thoroughly examination (first consultation, two times reevaluation of rehabilitation program). The first reevaluation done after 16 days of rehabilitation, patient's lower limb muscle strength improved (motor level of injury improved to level T8 with L2-S1 key muscles function by manual muscle testing (MMT) of L2,L3,L4,L5,S1 bilaterally improved from $44434 / 44334$ to $44444 / 44444$, patient able to walk from bed to bathroom independently without aid. There was improved of the level of sensory deficit, by pin prick-fine touch test, from the level of T7-T9 to T9-T10.

The sensation on sensory level of $\mathrm{T} 8$ was normal. Patient still has complained about the back pain even the numeric pain rating scale (NPRS) was better than the first consultation, from 5 to 3 .

Patient has a serial of bladder training and the 
urinal catheter already removed at the first rehabilitation reevaluation. There was still minimal pain when urinating, but there was no retention of urinary..

On the second reevaluation (day $21^{\text {st }}$ ), patient has improved of L2-S1 MMT to 55445/55445, able to walk independently with no back pain. There was still pain on changing position from sitting to upright.

Sensory function has restored to normal, and patient could urinate painless.

International Classification of functioning disability and health (ICF) has showed body function problem and weakness of both lower extremities have improved. There was restriction of participation, needed to assessed and facilitation to the job provider about patient function and ability needed at the working place.

Patient has high dose injection of Methylprednisolone, followed by tapering off, to decreased the swelling in the spinal cord. Along with two serial of antibiotics; ciprofloxacin $400 \mathrm{mg}$ and Ampicillin Sulbactam $1 \mathrm{~g}$ iv during the hospitalization. Serial of blood and urine tests have shown improvement of leucocyte, from 16.800 to $8.700 / \mathrm{dL}$ and urine bacterial from 25.520 .4 to $22.3 / \mathrm{uL}$. There was diplococcus bacteria, and no tuberculosis bacteria have found on phlegm.

Further education is needed for the patient and family to remind and motivate the patient to do Rehabilitation Program routinely, after discharge from hospital. Home program of strengthening exercise, by isotonic exercise is recommended for the patient. Patient has a semirigid Lumbosacral orthosis to stabilized the spine.

\section{DISCUSSION}

Patient has spinal cord injury by ASIA impairment scale (AIS) D on level of T6; Radiological findings in thoracolumbal MRI shown lesion at the thoracal level. There was no cerebro spinal fluid (CSF) analysis that could described the elevate of leucocyte and $\mathrm{IgG}$, as the implicated of the inflammatory (myelitis) sign.

Rehabilitation program have done for 3 weeks during the hospitalization, and the results were improvement of motoric, sensory and autonomic function after 16 days of program. Patient also has pharmacological therapy. Rehabilitation program consists of AAROM exercise, combined by walking exercise. The outcome were improvement of the strength of lower extremities, and ability to walk. Application of TENS was effective in reduce the back pain, caused by degenerative and myelitis process.

Calis M, et al. (2014) has proven that Rehabilitation program on transverse myelitis patient were increasing patient's strength and endurance, improving co-ordination, reducing spasticity and muscle wasting in paralyzed limbs, and regaining greater control over bladder and bowel function. They have used therapeutic exercises; passive and active ROM, muscle strengthening program and mobilization exercises along with neuro-muscular facilitation exercises, with results were improving of functional status assessed by Functional independent measure, Barthel index, Functional ambulatory scale, after 
5 days per weeks exercise, for 4 weeks total rehabilitation program. ${ }^{8}$

Christina L Sadwosky, et al. suggested that rehabilitation approach with activity-based restorative exercise by therapist in transverse myelitis patients, increase muscle strength, increase joint range of motion (ROM), improve muscle tone, reduce pain, and finally maximize functional mobility. The goal of sensory stimulation is to enhanced excitatory flow from muscle spindles to the motor neuron pools and depresses the inhibitory effect of the Golgi tendon organ. Rehabilitation exercise program varies from 2-5 days per week with recommendation for further home based rehabilitation programs designed to be functional and feasible in the context of daily living. ${ }^{9}$

Rehabilitation program in this case was to 2- 3 times/day and 2 days/week, was less frequent than Calis, ${ }^{8}$ but similar with Christina. ${ }^{9}$

Autonomic dysfunction as a retention urine in this case was treated with serial bladder training, which started on 3rd day admission with constant micturition evaluation every 1-2 hours interval, gradually increased interval time, as patient tolerated, up to 3-4 hours interval of micturition, for 3 weeks. As the result was patient able to voiding normally. This result in line with Calis case report has proven that Rehabilitation program improved bladder function. ${ }^{8}$

A case report by Alberto Ortega-Rosales, et al., in 2019, has proven Mycobacterium tuberculosis infection caused Acute Transverse Myelitis, and the patient has showed improvement after tuberculosis treatment. ${ }^{10}$ This result also confirmed by a clinical study by Feng Yanqing at al. in 2010 on Mycobacteria infection that caused incomplete transverse myelitis which showed improvement on clinical and spinal cord radiological MRI after anti tuberculosis treatment. ${ }^{11}$ In this case, the patient has still not free from the latent tuberculosis infection. Other bactery infection, such as diplococcus infection from the respiratory tract, can be the cause of myelitis. Most of the Transverse Myelitis were related to the streptococcus and pneumococcus infection, ${ }^{12}$ Ghita Ann Wiebe, et al. had reported a case of transverse myelitis related to diplococcus infection. ${ }^{13}$

\section{CONCLUSION}

Medical rehabilitation program (active range of motion exercise, combined with strengthening exercise, serial sensory stimulation and autonomic function retraining/bladder training) for 5 days a week along with pharmacological treatment for 3 weeks were effective to restore the function of Transverse Myelitis.

\section{REFERENCES}

1. Ropper AH, Samuels MA, Klein JP. Adams and Victor's Principles of Neurology. $10^{\text {th }}$ Ed. USA : McGraw Hill; 2015 : 922-923.

2. Minagar A, ed. Neuroinflamation. Acute Transverse Myelitis : Clinical Feature, Pathophysiology, and Treatment Options. $2^{\text {nd }}$ Ed. USA : Academic Press; 2018 : 141-161.

3. Darras B, Jones H, Ryan M, De Vivo D, editors. Neuromuscular Disorders of Infancy, Childhood, and Adolesence. $2^{\text {nd }}$ Ed. United Kingdom : Academic Press; 2015 : 385-386. 
4. Bhat A, Naguwa S, Cheema G, Gershwin ME. The epidemiology of transverse myelitis. Autoimmunity Reviews : Elsevier. 2010; 9: A395-A399. Available at: https:// www.ncbi.nlm.nih.gov/pubmed/20035902. Accessed August 26 ${ }^{\text {th }}, 2019$.

5. Frohman EM, Wingerchuk DM. Clinical Practice : Transverse Myelitis. The New England Journal of Medicine : NEJM. 2010; 8: 564-572. Available at: https://www.nejm. org/doi/full/10.1056/NEJMcp1001112. Accessed August 26 $6^{\text {th }}, 2019$.

6. Krishnan C, Kaplin AI, Deshpande DM, Pardo CA, Kerr DA. Transverse Myelitis: pathogenesis, diagnosis and treatment. Frontiers in Bioscience. 2014 ; 9: 1483-1499. Available at: https://www.researchgate.net/ publication/5242294_Transverse myelitis Pathogenesis_diagnosis and treatment. Accessed August 26 ${ }^{\text {th }}, 2019$.

7. World Health Organization. ICF : International Classification of Functioning, Disability and Health. Geneva : WHO Publication; 2001.

8. Calis M, Kirnap M, Calis H, Mistik S, Demir H. Rehabilitation results of patients with acute transverse myelitis. Bratisl Lek Listy. 2011; 112 (3): 154-156. Available at: http://bmj.fmed.uniba.sk/2011/11203-11. pdf. Accessed August 26 $6^{\text {th }}, 2019$.

9. Sadowsky CL, Becker Daniel, Bosques Glendaliz, Dean Janet M, McDonald John W, et al., Rehabilitation in transverse myelitis. Continuum (Minneap Minn): Lippincott Williams \& Wilkins. 2011; 8:816-830: 2011. Available at: https://www.academia.edu/27136301/ Rehabilitation_in_transverse myelitis?auto=download. $\quad$ Accessed August 27th 2019.

10. Ortega-Rosales A, Delgado-Torres N, Burneo-Rosales C. A rare neurological complication of tuberculosis : Transverse Myelitis. IDCases : Elsevier. 2019. Available at : https://www.ncbi.nlm.nih.gov/ pmc/articles/PMC6538955/\#_ffn_sectitle. Accessed September 17 $7^{\text {th }}, 2019$.

11. Feng Y, Guo N, Liu J, Chen X, Sun Q, Lai R et all. Mycobacterium Infection in Incomplete Transverse Myelitis is Refractory to Steroids : A Pilot Study. Clinical and Development Immunology : Hindawi Publishing Corporation. 2011. Available at : https:// www.ncbi.nlm.nih.gov/pubmed/21331384. Accessed September 19 $9^{\text {th }}, 2019$.

12. Williams T, Thorpe J. Post-invective transverse myelitis following Streptococcus pneumoniae meningitis with radiological features of acute disseminated encephalomyelitis : a case report. Jurnal of Medical Case Reports : BioMed Central. 2012. Available at : http://www. jmedicalcasereports.com/content/6/1/313. Accessed September 19th 2019.

13. Wiebe GA, Fanella S, Wrogemann J, Daymont C, Rafay M. Diffuse Bacterial Meningitis and Myelitis Secondary to a Diplococcus Organism. Canadian Journal of Neurological Sciences Inc. 2016; 192 194. Available at : https://www.cambridge. org/core/services/aop-cambridge-core/ content/view/9A3393433E13D7F3B25A99 3D7098DB2B/S031716711 5003170a.pdf/ diffuse bacterial_meningitis_and_myelitis secondary to a diplcoccus organism. pdf . Accessed September 19th 2019. 